\title{
GEOLOGICAL AND STRUCTURAL INFLUENCE ON GROUNDWATER DISTRIBUTION AND FLOW IN NGONG AREA, KENYA.
}

\author{
Mulwa, J.K., Gaciri, S.J., Barongo, J.O., Opiyo-Akech,N. and Kianji, G.K. \\ University of Nairobi, Department of Geology, P.O. Box 30197-00100 G.P.O Nairobi, Kenya
}

\begin{abstract}
Groundwater is increasingly becoming an important resource within and around the Ngong area, of Kenya. This is mainly as a result of increase in human population due to rural-urban migration, industrial expansion and farming activities. Ngong area forms a water catchment zone to the west of the city of Nairobi in Kenya. The geology of the area is comprised of volcanic layers of basalts, trachytes, phonolites and tuffs all overlain by thick layers of clay soil. The soil retains water for an extended period of time after the rains and this partly recharges aquifers in the area. Basalts and trachytes form good aquifers whereas tuffs are aquifers only when fractured. Faults delineated from a study of aerial photographs trend in a North-South direction in conformity with the structural pattern of the eastern branch of the Great Rift Valley. The influence of the faults on groundwater is two fold. They act as drainage channels to the flow of groundwater and also as aquifers in the area.
\end{abstract}

\section{INTRODUCTION}

Water is a vital component to the development of an area. Human settlement is to a large extent dependent on the availability of reliable sources of water preferably in close proximity to the settled localities. There has been a tremendous increase in human population in Ngong area, here in referred to as "the area", due to rural-urban migration. Moreover, there has been a lot of industrial expansion and farming activities within the area. These factors have overstretched the water requirements in the area, since it is required for industrial, agricultural, construction and domestic uses.

Surface water cannot be relied upon due to contamination. Groundwater therefore remains as the only reliable source of water supply. This study was therefore necessary so as to understand the factors influencing the distribution, flow and yield of groundwater.

The Kiseriam-Matathia area in which the study was carried is located about $30 \mathrm{~km}$ west of the city of Nairobi. It forms a water conservation zone to the east of Ngong hills in Kenya. The area lies at an altitude of about $1800 \mathrm{~m}$ above sea level. It forms the eastern flanks of the eastern branch of the Great Rift Valley. The area is approximately bounded by latitudes $1^{\circ} 19^{\prime} \mathrm{S}$ and $1^{\circ} 27^{\prime} \mathrm{S}$ and longitudes $36^{\circ} 37^{\prime} \mathrm{E}$ and $36^{\circ} 45^{\prime} \mathrm{E}$ (Figure 1).

The Ngong area's location on the eastern flank of the Kenya Rift Valley made it prone to subsequent movements during the formation of the Rift Valley. The development of the Kenya Rift Valley was accompanied by faulting, tectonic movement, and volcanicity. The shoulders and floor of the rift were therefore affected by these events and eventual intense weathering took place along the fault zone and fractures (Saggerson, 1991). Faults have influenced the occurrence of groundwater in terms of its distribution, flow and yield. When filled with weathered material, faults act as excellent aquifers. The yield from boreholes drilled into such faults is thus high. Alternatively, they act as drains, lowering the water table and thus affecting the distribution of groundwater (Mulwa, 2001). Further, faults act as barriers to the flow of groundwater if filled with impermeable material such as clays. These factors have a strong bearing on the aquifer yields through boreholes, static water levels, flow and hence distribution of groundwater and therefore would influence the amount of water available for abstraction in a faulted region. A thorough understanding of the actual influence of structures on groundwater was necessary for future planning on borehole drill sites in this area and in other areas of similar geological setting. 
To Nairobi

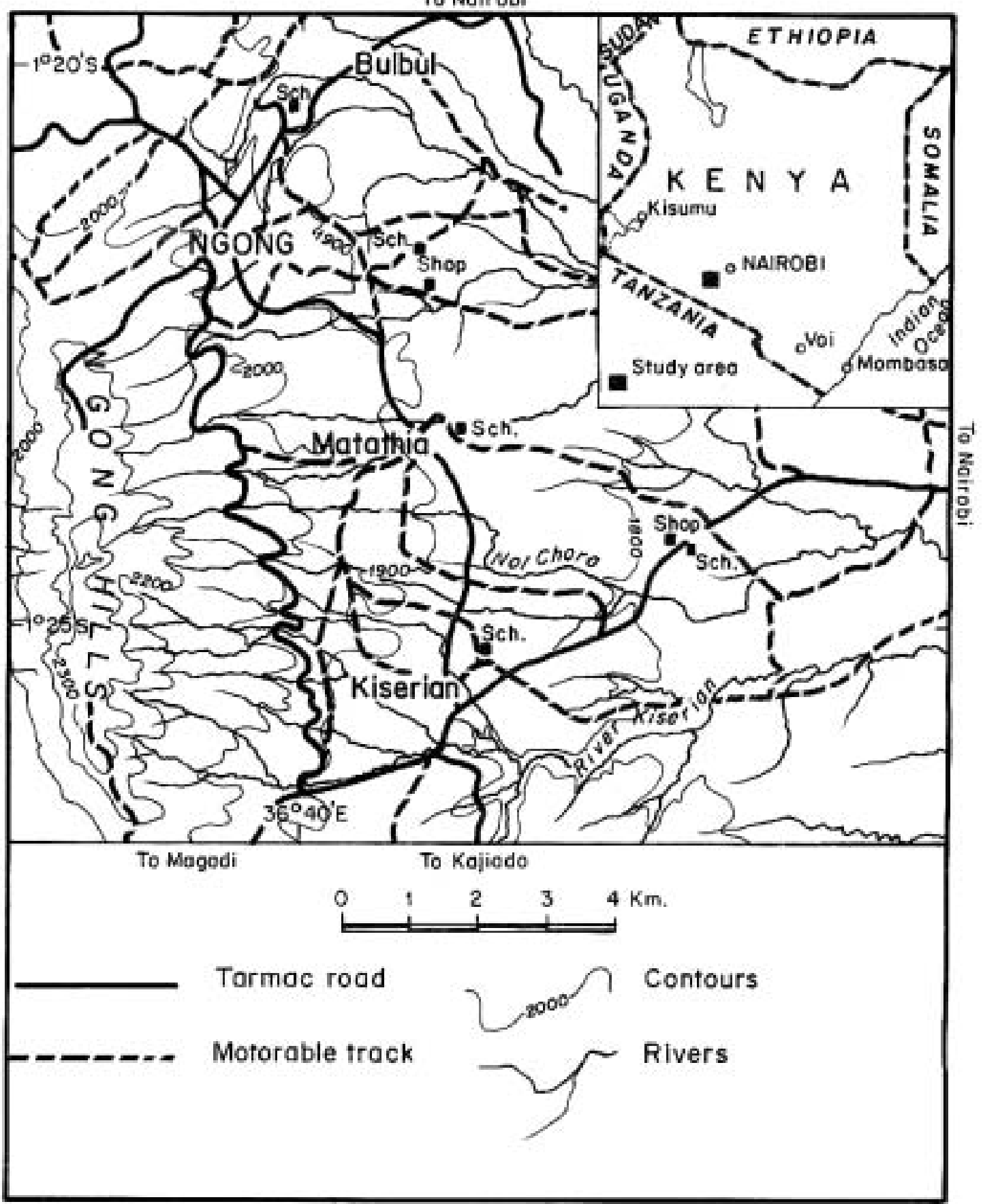

Figure 1: Location and physiography of Ngong area. 


\section{HYDROGEOLOGICALSETTING}

Ngong area is located to the east of Ngong hills which constitute the main catchment. Volcanic activity has dominated the geological history of the area since Miocene and has controlled the geomorphological evolution (Saggerson, 1991). The area is underlain by tertiary volcanic rocks, namely, Ngong basalts, Ol Doinyo Narok agglomerate, Limuru quartz trachyte, Kerichwa valley tuff,
Nairobi trachyte, Nairobi phonolite, Mbagathi trachyte, Kandizi phonolite and Ol Esayeti phonolite. Recent deposits of quaternary age are comprised of sediments and lucustrine deposits (Figure 2). The volcanic rocks are associated with the numerous volcanic activities along the Kenya rift valley. They flowed eastwards onto a warped and partly dissected pre-miocene erosion surface underlain by older crystalline rocks (Saggerson, 1991).

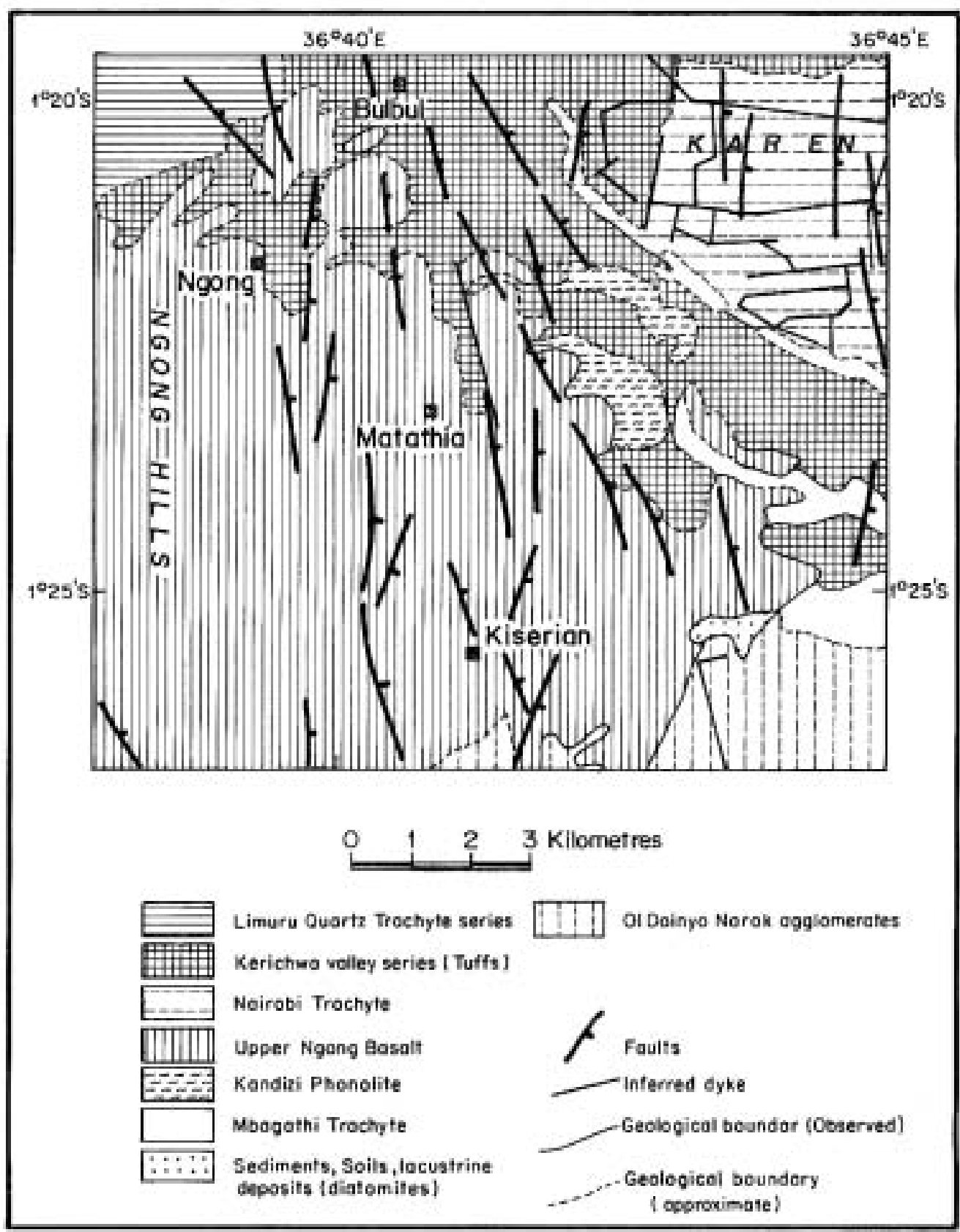

Figure 2. Geology of Ngong area. 
The rift region within the area is characterised by subsidiary internal drainage; outgoing drainage being virtually absent. Surface water runoff either collects in numerous depressions or disappears in fissures (Mulwa, 2001). Only storm water in the eastern border zone leaves the area through a few gaps in faults occurring in the area (Gevaerts, 1964). Two major perennial rivers draining through the area are Kiserian and Ngong rivers. Seasonal streams include Kandizi and Nol Chora. Such streams are in their youthful stage and as such, they have cut deep and steep "V" shaped valleys in the lavas. The streams assume a parallel pattern on the higher slopes due to the linear elongation of the ridges. This drainage is characteristic of volcanic areas (Saggerson, 1991).

Aquifers in the area are replenished by part of the precipitation that infiltrates underground. The aquifers are tapped through boreholes (Figure 3 and Table 1) and constitute an important source of water supply in the area. Lithological variations coupled with varied degree of weathering and fracturing attribute a high degree of inhomogeneity in the hydrogeological characteristics of

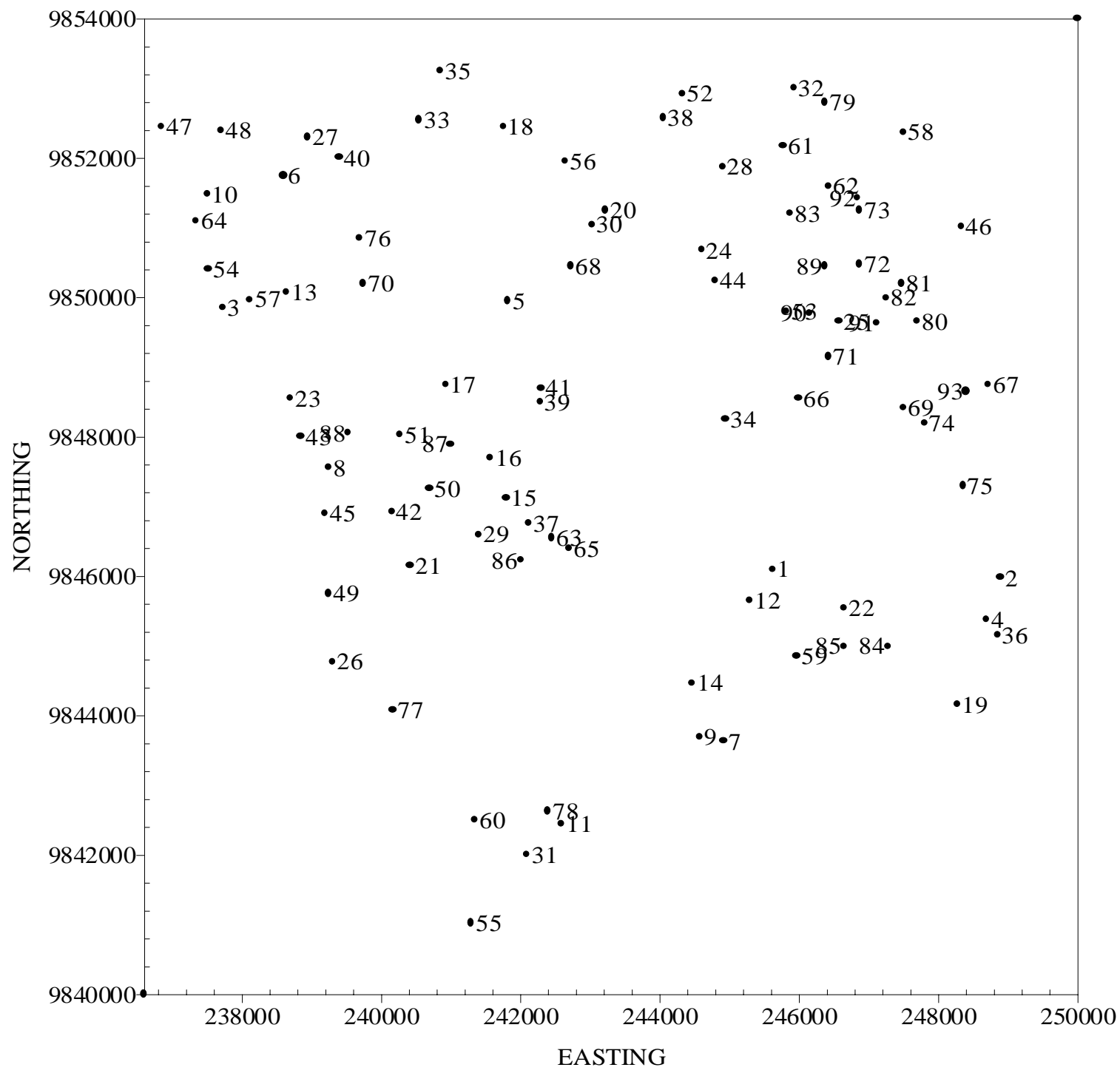

Figure 3: Boreholes in Ngong area 
Geological and Structural Influence on Groundwater Distribution and Flow in Ngong Area, Kenya

Table 1. Boreholes in Ngong area

\begin{tabular}{|c|c|c|c|}
\hline 1 & C 7285 & 245625 & 9846100 \\
\hline 2 & C 10297 & 248900 & 9845975 \\
\hline 3 & P 6 & 237725 & 9849850 \\
\hline 4 & C 10132 & 248700 & 9845375 \\
\hline 5 & C 588 & 241825 & 9849950 \\
\hline 6 & P 2 & 238600 & 9851750 \\
\hline 7 & C 10769 & 244925 & 9843625 \\
\hline 8 & C 9953 & 239250 & 9847550 \\
\hline 9 & C 9727 & 244575 & 9843700 \\
\hline 10 & P 4 & 237500 & 9851475 \\
\hline 11 & C 4863 & 242600 & 9842450 \\
\hline 12 & C 10439 & 245300 & 9845650 \\
\hline 13 & P 12 & 238650 & 9850075 \\
\hline 14 & C 5408 & 244475 & 9844475 \\
\hline 15 & C 6211 & 241800 & 9847125 \\
\hline 16 & C 6210 & 241575 & 9847700 \\
\hline 17 & C 9689 & 240925 & 9848750 \\
\hline 18 & C 10082 & 241750 & 9852450 \\
\hline 19 & C 4867 & 248275 & 9844150 \\
\hline 20 & C 1648 & 243225 & 9851250 \\
\hline 21 & C 4743 & 240425 & 9846150 \\
\hline 22 & C 7372 & 246650 & 9845550 \\
\hline 23 & C 8881 & 238700 & 9848550 \\
\hline 24 & C 9774 & 244600 & 9850675 \\
\hline 25 & C 1659 & 246575 & 9849650 \\
\hline 26 & C 5798 & 239300 & 9844775 \\
\hline 27 & C 9423 & 238950 & 9852300 \\
\hline 28 & C 1270 & 244900 & 9851875 \\
\hline 29 & C 4092 & 241400 & 9846600 \\
\hline 30 & C 4190 & 243025 & 9851050 \\
\hline 31 & C 7736 & 242100 & 9842000 \\
\hline 32 & C 1907 & 245925 & 9853000 \\
\hline 33 & C 5500 & 240550 & 9852550 \\
\hline 34 & C 4938 & 244950 & 9848250 \\
\hline 35 & C 9725 & 240850 & 9853250 \\
\hline 36 & C 11361 & 248850 & 9845150 \\
\hline 37 & C 4186 & 242125 & 9846750 \\
\hline 38 & C 4987 & 244050 & 9852575 \\
\hline 39 & C 4967 & 242275 & 9848500 \\
\hline 40 & C 2294 & 239400 & 9852000 \\
\hline 41 & C 4201 & 242300 & 9848700 \\
\hline 42 & C 11131 & 240150 & 9846925 \\
\hline 43 & C 6494 & 238850 & 9848000 \\
\hline 44 & C 8069 & 244800 & 9850250 \\
\hline 45 & C 6979 & 239200 & 9846900 \\
\hline 46 & C 5563 & 248325 & 9851025 \\
\hline 47 & C 10626 & 236850 & 9852450 \\
\hline
\end{tabular}

\begin{tabular}{|c|c|c|c|}
\hline 48 & C 9156 & 237700 & 9852400 \\
\hline 49 & C 10063 & 239250 & 9845750 \\
\hline 50 & C 11164 & 240700 & 9847250 \\
\hline 51 & C 6081 & 240275 & 9848025 \\
\hline 52 & C 2254 & 244325 & 9852925 \\
\hline 53 & C 9671 & 245825 & 9849800 \\
\hline 54 & C 6925 & 237525 & 9850400 \\
\hline 55 & C 1294 & 241300 & 9841025 \\
\hline 56 & C 10879 & 242650 & 9851950 \\
\hline 57 & C 6965 & 238125 & 9849975 \\
\hline 58 & C 5876 & 247500 & 9852375 \\
\hline 59 & C 5397 & 245975 & 9844850 \\
\hline 60 & C 10624 & 241350 & 9842500 \\
\hline 61 & C 10762 & 245775 & 9852175 \\
\hline 62 & C 4840 & 246425 & 9851600 \\
\hline 63 & C 4200 & 242450 & 9846550 \\
\hline 64 & C 10190 & 237350 & 9851100 \\
\hline 65 & C 4966 & 242700 & 9846400 \\
\hline 66 & C 4624 & 246000 & 9848550 \\
\hline 67 & C 6954 & 248725 & 9848750 \\
\hline 68 & C 4968 & 242725 & 9850450 \\
\hline 69 & C 10055 & 247500 & 9848425 \\
\hline 70 & C 5117 & 239750 & 9850200 \\
\hline 71 & C 6223 & 246425 & 9849150 \\
\hline 72 & C 10339 & 246875 & 9850475 \\
\hline 73 & C 10355 & 246875 & 9851250 \\
\hline 74 & C 10236 & 247800 & 9848200 \\
\hline 75 & C 3886 & 248350 & 9847300 \\
\hline 76 & C 3937 & 239700 & 9850850 \\
\hline 77 & C 6216 & 240175 & 9844075 \\
\hline 78 & C 4199 & 242400 & 9842625 \\
\hline 79 & C 1910 & 246375 & 9852800 \\
\hline 80 & C 10444 & 247700 & 9849650 \\
\hline 81 & C 9647 & 247475 & 9850200 \\
\hline 82 & C 9951 & 247250 & 9850000 \\
\hline 83 & C 7220 & 245875 & 9851200 \\
\hline 84 & C 5914 & 247275 & 9845000 \\
\hline 85 & C 7403 & 246650 & 9845000 \\
\hline 86 & C 7336 & 242000 & 9846225 \\
\hline 87 & C 10487 & 241000 & 9847900 \\
\hline 88 & C 6099 & 239525 & 9848050 \\
\hline 89 & C 1781 & 246375 & 9850450 \\
\hline 90 & C 1171 & 246150 & 9849775 \\
\hline 91 & C 1799 & 247125 & 9849625 \\
\hline 92 & C 4148 & 246850 & 9851425 \\
\hline 93 & C 6483 & 248400 & 9848650 \\
\hline
\end{tabular}


different aquifers. This inhomogeneous character causes aquifer yields to vary over a continuous area. Aquifers in the area are classified into four types.

i) Sands and sediment deposits intercalated in tuff, in which case, Saggerson (1991) and Gevaerts (1964) concur that most aquifers are either fluviatile or lacustrine deposits intercalated in most formations.

ii) Rock formations with an appreciably good porosity and permeability. These types of aquifers occur in formations such as weathered basalt, trachytes and tuffs.

iii) Contact between two rock formations such as basalt and tuffs or sands and sediments intercalated in weathered tuff. These contacts are the old land surfaces reported by Saggerson (1991) and Gevaerts (1964). iv) Fractured aquifers in different rock formations.

\section{ANALYTICAL PROCEDURESANDMETHODS}

Black and white aerial photographs at the scale of 1:25,000 were used in the identification of faults and fractures in the area. These aerial photographs of the 78/3B series were taken in December 1978 by Map survey. Interpretation criteria used is based on Sabins (1978) and, Lillesand and Keifer (1979). A Topcon mirror stereoscope was used in the interpretation of structural data. The data was plotted on transparent templates at same scale as that of aerial photographs, after which a pantograph was used was used to transfer the structural data onto a topographic map (scale 1:50,000). Figure 4 shows the fracture zones identified during this study.

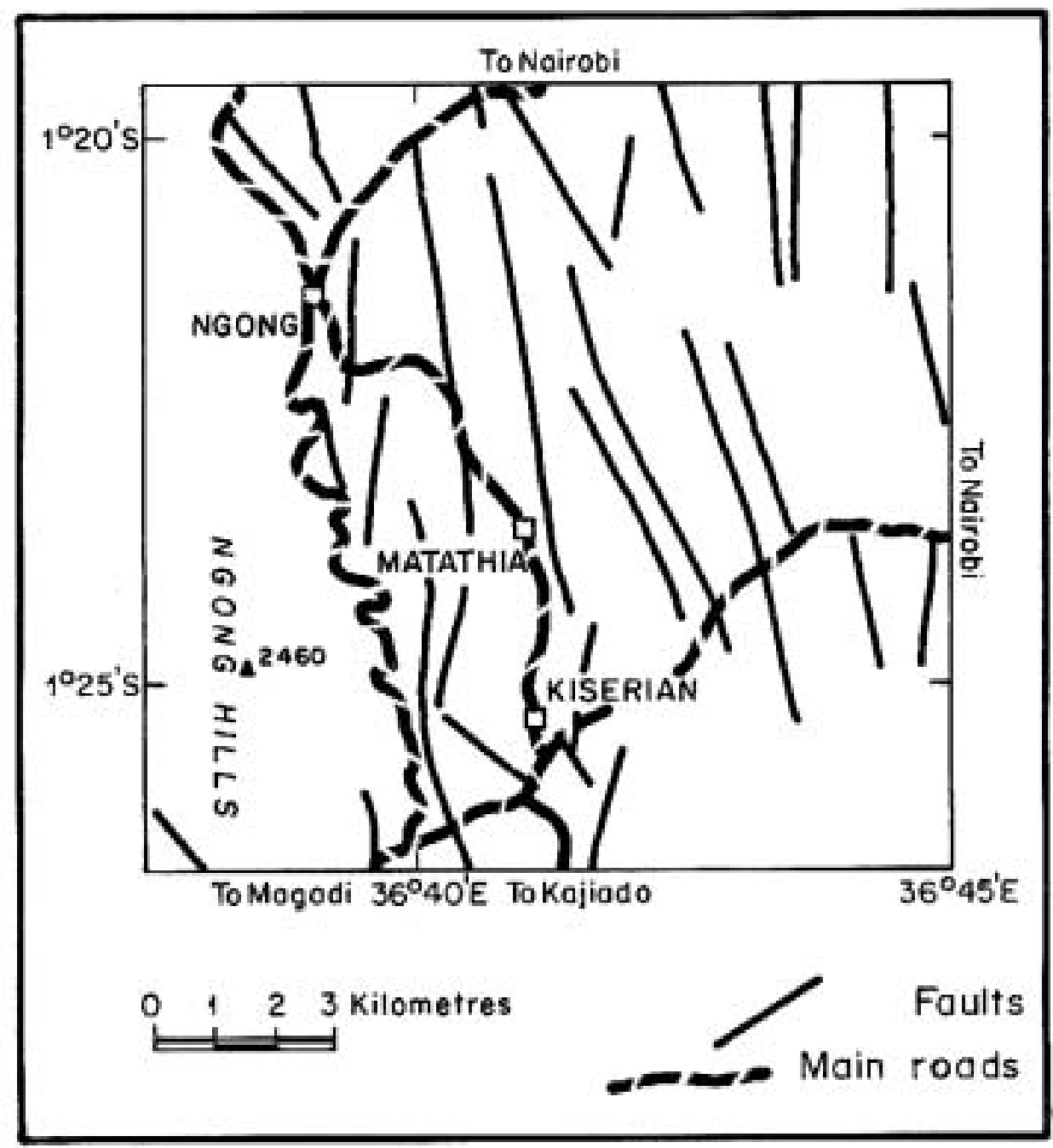

Figure 4: Structural map of Ngong area 
Ninety three boreholes were visited in the area and their locations were noted together with the water rest levels, yield and total depths. Water samples were collected from these boreholes for the determination of certain physical and chemical parameters. These parameters are not outlined in this paper.

\section{RESULTS AND DISCUSSION}

In order to understand the geological and structural influence on groundwater, three maps were prepared as described below: -

\section{Piezometric map}

The groundwater flow map (Figure 5) was prepared by reducing the local piezometric levels for about ninety (90) boreholes in the area to ordinance datum (mean sea level) and contouring at $20 \mathrm{~m}$ interval. Such a map is important because it shows the recharge and discharge zones in an area. It also shows how groundwater flow is influenced by faults (Davies and Dewiest, 1966; Mailu, 1983).

The piezometric map in this study shows that groundwater flows from elevated regions (the Ngong hills in the west)

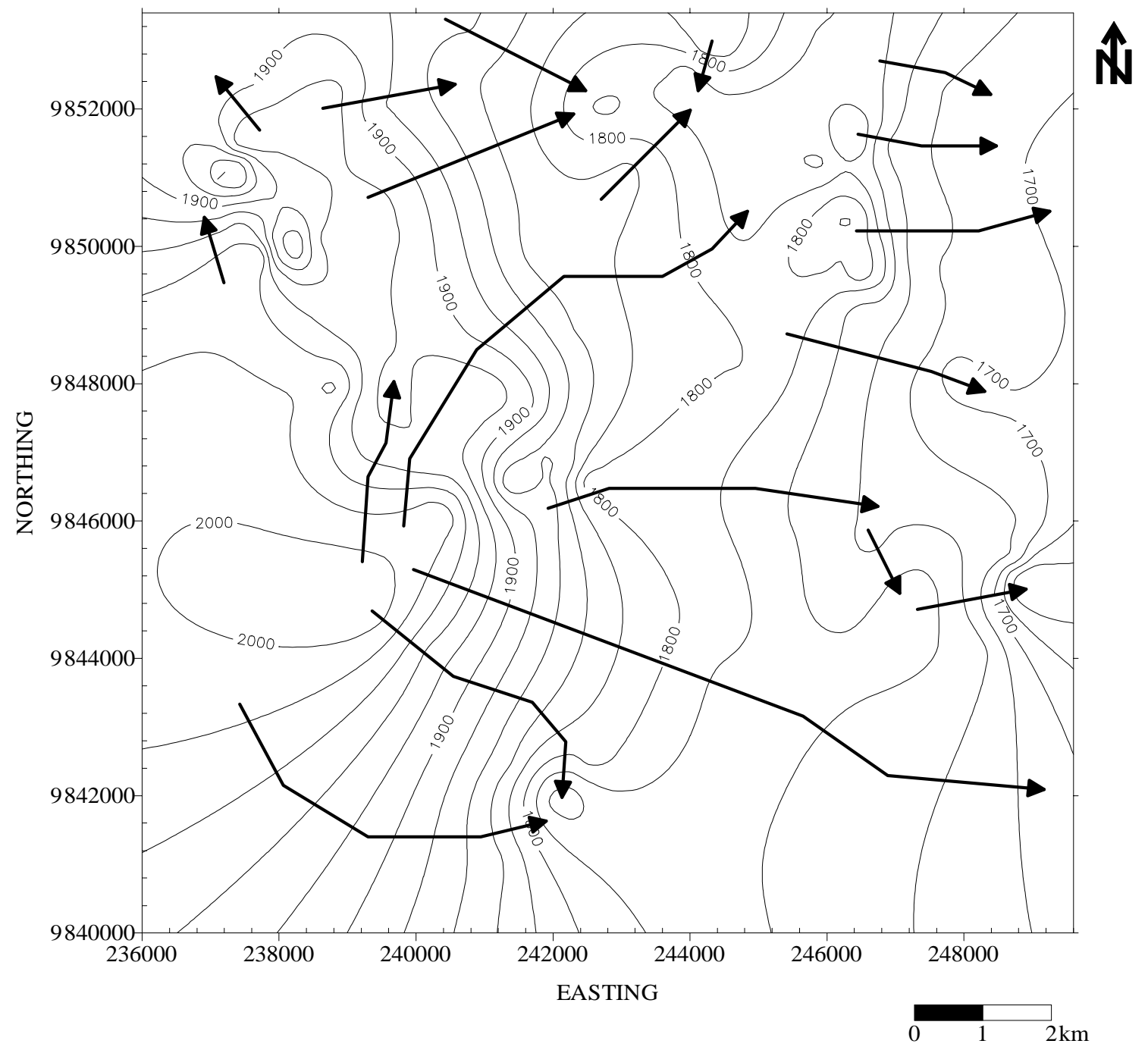

Figure 5: Piezometric map of Ngong area. 
to low lying discharge areas in a NE and SW directions. Faulting is an outstanding phenomenon in the area due to its location on the eastern branch of the East African Rift System and the flow model is modified by the presence of major faults. As a result, flow occurs both laterally (NE and SW) and occasionally, longitudinally (N-S). A characteristic feature of aquifers tapped through boreholes located along or close to faults which deviate the lateral flow of groundwater is that all of them have water yield in excess of $10 \mathrm{~m} 3 / \mathrm{hr}$ which can be considered to be a reasonably good yield. Such boreholes include C10624, C7736, C9423, C3937, C5117, C6099, C5500, C4092, C4201, C4967, C4200 and C4199 (Figure 3 and Table 1). The faults therefore act as conduits through which groundwater flows.

\section{Aquifer yields and total depths of boreholes}

A second map showing aquifer yields as tapped through boreholes was prepared by contouring the water yield at intervals of $2 \mathrm{~m} 3 / \mathrm{hr}$. This map is important because it relates the water yield from aquifers to geology and structures. About ninety (90) boreholes were considered for this task. Figures $6 \mathrm{a}$ and $6 \mathrm{~b}$ are contour maps of the aquifer yields as tapped through boreholes and the total depths of boreholes reduced to ordinance datum, respectively. A comparative study between aquifer yields and total depths of boreholes is made in the foregoing discussion.

It is evident from figure 6a that aquifers yielding water of $\Rightarrow 10 \mathrm{~m} 3 / \mathrm{hr}$ are located in the west and central region of Ngong area. The high yield from these aquifers can be explained by a correlation of the piezometric (Figure 5) and aquifer yield (Figure 6a) maps. The regions with aquifers yielding over $10 \mathrm{~m} 3 / \mathrm{hr}$ are those which are immediately recharged by faults and rainwater infiltrating into the ground. The discharge regions to the east have low yields, less than or equal to $10 \mathrm{~m} 3 / \mathrm{hr}$, except in very few areas with anomalous high yield ranging between $10 \mathrm{~m} 3 / \mathrm{hr}$ and 18 m3/hr (Mulwa, 2001).

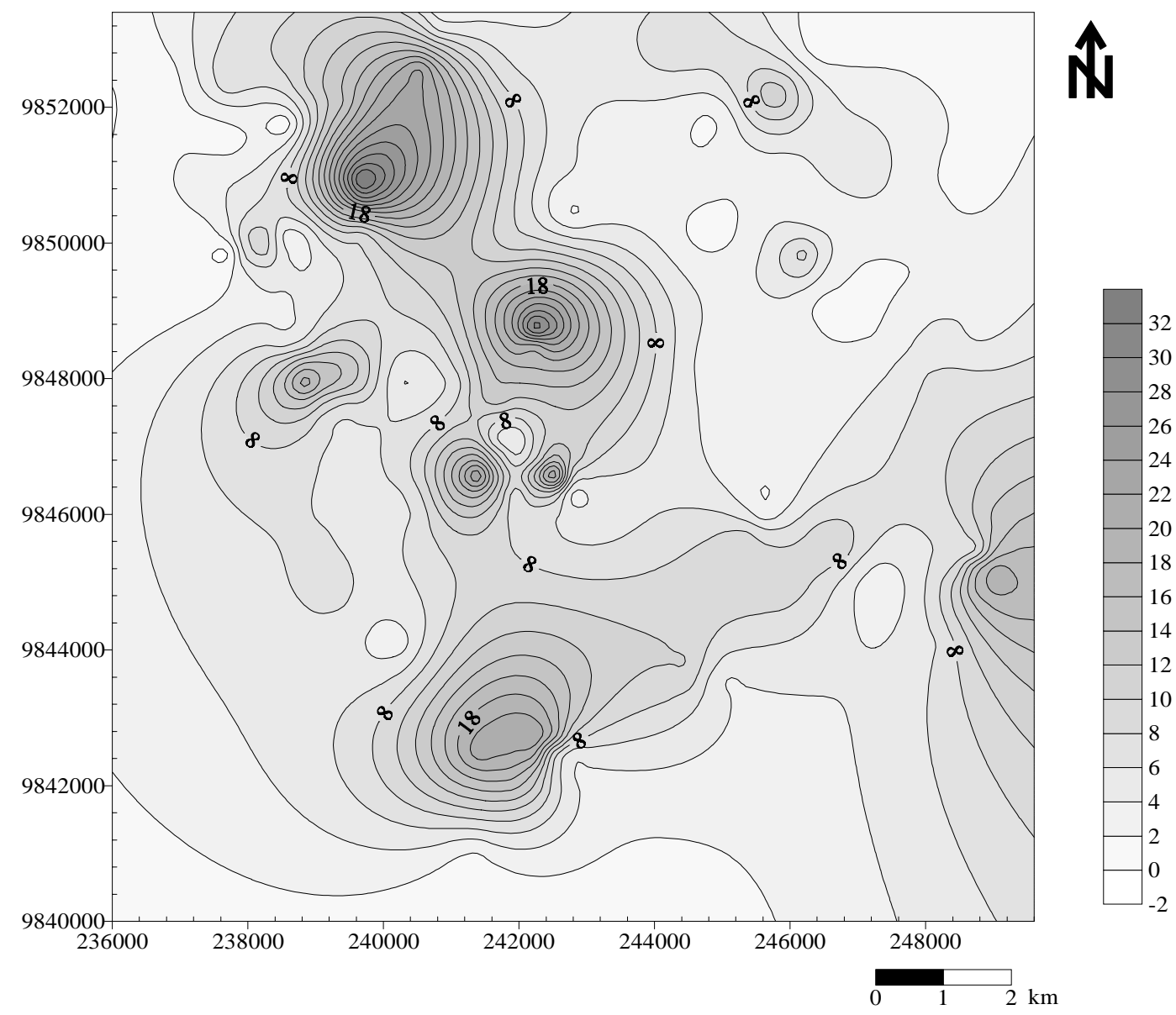

Figure 6a: Aquifer yield tapped by boreholes in Ngong area 


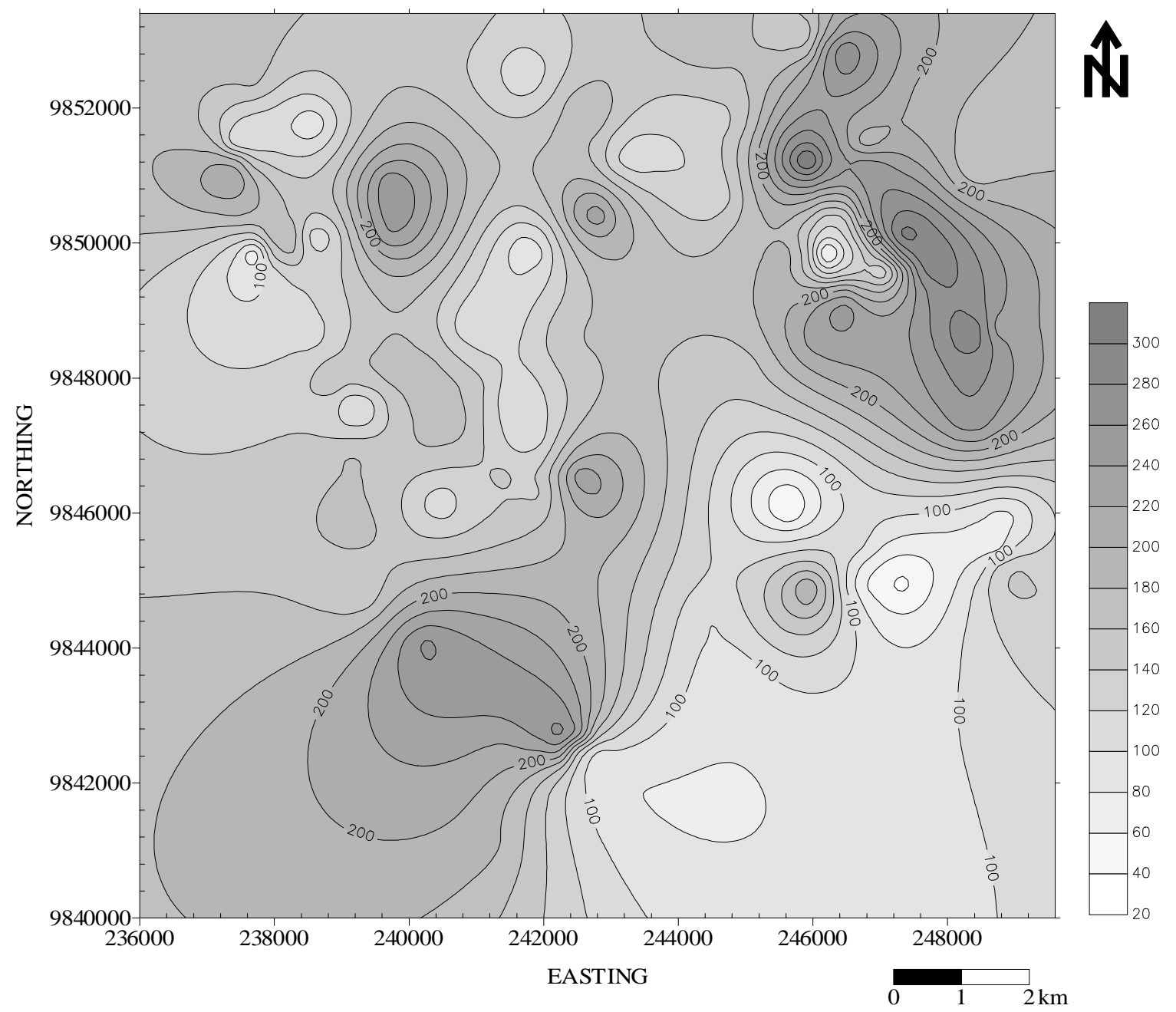

Figure 6b. Total depths of boreholes in Ngong area

Aquifers on fault zones have a mean yield of $21 \mathrm{~m} 3 / \mathrm{hr}$ and boreholes sited on such fault zones are quite deep, with an average total depth of $189 \mathrm{~m}$ (Figure 6b). However, the respective aquifers were struck at relatively shallow depths. The average aquifer depth is $130 \mathrm{~m}$ below ground surface. Aquifers yielding more than $20 \mathrm{~m} 3 / \mathrm{hr}$ of water are only located on fault zones in the study area. Such aquifers, for example, are those tapped by boreholes C10624, C3937, C5500, C4092, C4201 and C4200 and their mean yield is $27 \mathrm{~m} 3 / \mathrm{hr}$. Figures $6 \mathrm{a}$ and $6 \mathrm{~b}$ show that aquifers yielding over $20 \mathrm{~m} 3 / \mathrm{hr}$ of water are associated with depths exceeding $180 \mathrm{~m}$ below the ground surface. These aquifers occur in the central region of Ngong area where faulting is a dominant phenomena (Mulwa, 2001).
In Karen area which is located to the northeast, the mean borehole and aquifer depths are $206 \mathrm{~m}$ and $163 \mathrm{~m}$, respectively, below the ground surface. Inspite of these depths, the mean aquifer yield is quite low and is about 4.2 $\mathrm{m} 3 / \mathrm{hr}$. The low yield can be explained by the fact that Karen area is in a discharge zone and the high number of boreholes imply that the rate of water abstraction is far much greater than the rate at which aquifers are replenished (Mulwa, 2001). The influence of fractured aquifers in Karen area is however evident. Boreholes C 2254, C 10762 and C 10355 in this area are sited in fractured aquifers yielding about 10 $\mathrm{m} 3 / \mathrm{hr}$ of water. Hence, faults in Ngong area are excellent aquifers. 
Rock formations in the area are deeply weathered, particularly the basalts, trachytes and tuffs with secondary weathering being associated with fracturing (Saggerson, 1991; Gevaerts, 1964). Depressions associated with faulting and differential erosion are a common feature in this area. High rainfall and relatively low evaporation are characteristics of this area. These conditions are favourable for infiltration of a great quantity of water into the porous and permeable rocks.

The permeability of rocks is dependent on whether they are fractured and/or weathered or reworked and altered (Mulwa, 2001). High or low aquifer yields cannot be associated with a particular aquifer formation. All aquifers generally have either high $(>10 \mathrm{~m} 3 / \mathrm{hr})$ or low $(<10 \mathrm{~m} 3 / \mathrm{hr})$ water yield and are associated with weathered trachytes, fractured and/or weathered vesicular basalt and tuff, and volcanic sediments (old land surfaces), (Gevaerts, 1964). The water yield in Ngong area therefore depends on the location of an aquifer, whether in the recharge or discharge region. Multiple aquifers also contribute to excessively high yield. An example of a borehole with multiple aquifers and excessively high yield (>20m3/hr) is C3937. However, the occurrence of multiple aquifers in boreholes does not always guarantee high water yield. Some boreholes associated with multiple aquifers have low water yield whereas others associated with only a single aquifer have high water yield.

In the western region on the flanks of Ngong hills, recharge is excellent due to high rainfall and low evaporation, which favours infiltration of a good quantity of rainwater. Aquifers in the area tend to be modified by tectonic movements of the Rift Valley, both on a small scale by creating local fracture systems which comprise many aquifers and, to a large scale, forming regional hydraulic barrier or shatter zones of enhanced permeability (Sikes, 1934; Gevaerts, 1964).

\section{CONCLUSION}

Groundwater in Ngong area occurs within weathered and/ or fractured volcanics, and contact zones of different lithological units (old land surfaces). The groundwater potential in the area is generally good since the mean yield of all aquifers is $7.28 \mathrm{~m} 3 / \mathrm{hr}$ with a standard deviation of $6.85 \mathrm{~m} 3 / \mathrm{hr}$. Aquifers on fault zones have the highest water yield and are very deep as depicted by the depths of boreholes tapping water from such aquifers. The depths of these boreholes signify that the faults have drained groundwater to deeper levels. Clay layers and dense compact rock units underlying aquifers often act as controls to the downward migration of groundwater (Kulkarni and Deolankar, 1993). Their absence in Ngong area (Mulwa, 2001) has contributed to migration of groundwater to deeper levels, especially along the faults. The faults in the area are excellent aquifers and also conduits to the flow of groundwater.

Ngong hills is the catchment zone in the area and is responsible for recharging aquifers on fault zones immediately to the east. The groundwater flow direction determined from the piezometric map (Figure 5) shows that the recharge zone is the western region and the discharge zone is the eastern region. High water yield from aquifers $(>10 \mathrm{~m} 3 / \mathrm{hr}$ ) in the recharge zone is due to an immediate recharge by faults or rainwater infiltrating into the subsurface. The discharge region is characterised by aquifer yields either less than or equal to $10 \mathrm{~m} 3 / \mathrm{hr}$ except in very few anomalous cases such as the case of aquifers tapped by boreholes $\mathrm{C} 10762$ and $\mathrm{C} 11361$. The water yield from these aquifers is $13 \mathrm{~m} 3 / \mathrm{hr}$ and $20 \mathrm{~m} 3 / \mathrm{hr}$, respectively. The excessively high yield from aquifers tapped through boreholes in the central region of Ngong area, mean $21 \mathrm{~m} 3 /$ $\mathrm{hr}$, is due to the influence of the numerous faults in this region. These faults have created a 'depression' in a N-S direction where water collects first before being discharged towards the east. The longitudinal flow (N-S) of groundwater along the fault zones has led to deeper flow paths.

Although high or low water yield from aquifers cannot be specifically associated with a particular aquifer formation, basalt accounts for $75 \%$ of all aquifer formations because of its relatively high porosity and permeability. The porosity and permeability are influenced by fracturing and secondary weathering (Mulwa, 2001) and the presence of vesicles and/or amygdales (Kulkarni and Deolankar, 1993) which store and transmit water easily. Most of the deep aquifers in the area are comprised of basalt. Shallow aquifers are comprised of weathered and to a lesser extent, fractured and weathered trachytes. The trachytes account for $14 \%$ of all aquifers in Ngong area. Intermediate aquifers are comprised of weathered and jointed tuff, and account for about $6 \%$ of aquifers in Ngong area (Mulwa, 2001).

There is a high concentration of boreholes in Karen area in comparison to other areas. The low aquifer yield in this area signifies that it is already under a regime of overexploitation. 


\section{ACKNOWLEDGEMENT}

We wish to thank the University of Nairobi for the financial support to undertake this study. Special thanks are due to the Ministry of water resources development and management for providing most of the borehole data used in this study. We are also indebted to the departments of geology and surveying and photogrammetry, University of Nairobi, for facilitating this study to be undertaken, and for the analysis and interpretation of structural data, respectively.

\section{REFERENCES}

Davies, S.N. and Dewiest, R.J.M., 1966. Hydrogeology. John Wiley and Sons, London.

Gevaerts, E.A.L., 1964. Hydrogeology of the Nairobi area. Tech. Rep. No.1, Water Dev. Dept.
Kulkarni, H. and Deolankar, S.B. 1993. Groundwater abstraction from shallow unconfined Deccan basaltic aquifers of Maharashtra,India; In: Selected papers on Environmental Hydrogeology, Vol.4, pp.107-119.

Lillesand, T.M. and Kieffer, R.W., 1979. Remote sensing and image interpretation. John Wiley and sons, New York.

Mailu, G.M., 1983. The Hydrogeology of the Athi basin. M.Sc. Thesis, University of Nairobi, Unpubl.

Mulwa, J.K., 2001. Geological and structural set-up of Kiserian-Matathia area and its influence on groundwater distribution and flow. M.Sc. Thesis, University of Nairobi, Unpubl.

Sabins, F.F.JR., 1987. Remote sensing, principles and interpretation. W.H.Freeman and Co., New York.

Saggerson, E.P., 1991. Geology of the Nairobi area. Rep. No.98, Geol. Surv. Kenya.

Sikes, H.L., 1934. The underground water resources of Kenya colony. London: Crown Agents. 